\title{
Evaluation of Different Fungicides against Leaf Blight (Alternaria triticina) of Wheat under in vitro Condition
}

\author{
Mahesh Kommeta $^{1 *}$, I.B. Kapadiya ${ }^{2}$ and L.F. Akbari ${ }^{1}$ \\ ${ }^{1}$ Department of Plant Pathology, Junagadh Agricultural University, \\ Junagadh, Gujarat - 362 001, India \\ ${ }^{2}$ Wheat Research Station, Junagadh Agricultural University, Junagadh, \\ Gujarat - 362 001, India \\ *Corresponding author
}

\begin{abstract}
A B S T R A C T
\section{Keywords}

Alternaria triticina, leaf blight, Wheat, Fungicides, in vitro condition, RBD with factorial

Article Info

Accepted:

15 May 2019

Available Online:

10 June 2019

Considering the importance of leaf blight of wheat caused by Alternaria triticina, a in vitro study was conducted using different fungicides using poisoned food technique. In laboratory screening, non-systemic fungicides viz., mancozeb $75 \%$ WP and propineb $70 \%$ WP were found most effective with 89.41 and 88.70 per cent fungal growth inhibition, respectively. While systemic fungicides viz., propiconazole $25 \% \mathrm{EC}$ and hexaconazole $5 \%$ EC proved most effective with 96.00 and 90.33 per cent fungal growth inhibition, respectively. But in combination fungicides viz., azoxystrobin $11 \%+$ tebuconazole $18.30 \% \mathrm{WP}$, hexaconazole $4 \%+$ zineb $68 \%$ WP and carboxin $37.5 \%+$ thiram $37.5 \% \mathrm{SD}$ were found most effective with cent per cent growth inhibition of fungus.

\section{Introduction}

Wheat (Triticum aestivum L.) is the world most widely cultivated food crop. In India wheat is second important staple food crop. Globally wheat has 224.98 million hectares area, 735.50 million metric tonnes production and 3.27 metric tonnes per hectare productivity and in India wheat has 30.78 million hectares area, 98.51 million metric tonnes production and 3.20 metric tonnes per hectare productivity during 2016-17 (Anon., 2018). In Gujarat wheat has 0.99 million

hectares area, 2.73 million metric tonnes production and 2.75 metric tonnes per hectare productivity during 2016-17 (Anon., 2017). Soil with a clay loam or loam texture, good structure and moderate water holding capacity are ideal for wheat cultivation. The major wheat growing countries are United States, China, Morocco, Algeria, Italy, Syria, USSR, Iran, Argentina and India. Alternaria leaf spot of wheat caused by Alternaria triticina has attained importance in northeastern and northwestern plain zone during recent years due to significant losses The loss of yield due to this
\end{abstract}


disease vary upto $29.4-43.2$ per cent beside reduction of 15.2- 30.5 percent in 1000 grain weight. The disease first appears as small, oval, discoloured lesion which are irregularly scattered on the leaves. These spots become irregular in shape with increase in size and appear brown to gray in colour. A bright yellow halo surrounds the spots. Several lesions coalesce to cover large areas and cause death of the entire leaf. In severe cases the leaf starts drying from the tip. Host range of the species is confined to wheat varieties only. Thus, the present investigation entitled "evaluation of different fungicides against leaf blight (Alternaria triticina) of wheat under in vitro condition" was proposed with the objective to evaluate the efficacy of fungicides on disease intensity.

\section{Materials and Methods}

Mycelial growth inhibition activities of different concentration of fungicides were tested against Alternaria triticina under in vitro condition by employing poisoned food technique of Bagchi and Das (1968) using Potato Dextrose Agar (PDA) as a germinating medium. The quantity of each fungicides required were incorporated into autoclaved measured PDA medium before solidification with micropipette and then medium were poured into sterilized Petri dishes $(90 \mathrm{~mm}$ dia.) in equal quantity ( $20 \mathrm{ml}$ per Petri dish) to form a uniform layer. The experiment was arranged in FCRD with three repetitions.

These plates were then allowed to solidify. After solidification the plates were inoculated with an actively growing fungal mycelial bit of $4 \mathrm{~mm}$ diameter which was transferred under aseptic conditions over the solidified PDA medium. The mycelial disc was placed in the center of plates in an inverted position to make a direct contact with the poisoned medium. Then Petri dishes were incubated at $25 \pm 1{ }^{\circ} \mathrm{C}$ for 10 days and observations were recorded on radial growth of mycelium in treated and control plates. Inoculated Petri dishes containing PDA medium without fungicides were served as control. The radial growths of the fungal colonies were measured from two different angles in millimeter $(\mathrm{mm})$ and the average values were calculated. The per cent growth inhibition of the fungus in each treatment was calculated by using following formula (Vincent, 1947)

PGI $=\frac{\text { C }-\mathrm{T}}{\mathrm{C}}$

Where,

PGI $=$ Per cent growth inhibition

$\mathrm{C}=$ Average growth diameter of test pathogen in control $\left(\mathrm{mm}^{2}\right)$

$\mathrm{T}=$ Average growth diameter of test pathogen in treatments $\left(\mathrm{mm}^{2}\right)$

Experiment was laid out with seven treatments with three repetitions. Completely Randomized Block Design with factorial concept was used for analyzing the data.

\section{Results and Discussion}

The results were discussed in Tab.1, Tab.2, Tab.3. Among different non-systemic fungicides mancozeb $75 \% \mathrm{WP}$ and propineb $70 \%$ WP gave mycelial growth inhibition of 87.74, 88.89, 90.04, 90.96 and 86.15, 87.56, 90.9690 .15 per cent at concentrations 500, 1000, 1500 and $2000 \mathrm{ppm}$, respectively which were found best treatments for inhibiting the growth of mycelium of A. triticina under in vitro condition. Metiram $55 \% \mathrm{WG}$ was found next best effective fungicide gave 75.78, $86.85,90.00,92.37$ per cent mycelial growth inhibition at 500, 1000, 1500 and $2000 \mathrm{ppm}$ concentrations, respectively. Thiram $75 \%$ 
WP gave $80.74,84.07,88.78$ and 91.26 per cent and zineb $75 \%$ WP gave 64.22, 65.44, 70.44 and 84.33 per cent mycelial growth inhibition of the fungus at 500, 1000, 1500, 2000 ppm concentration, respectively. Copper oxychloride $50 \%$ WP showed mycelial growth inhibition 53.70, 65.96, 75.52 and 76.41 per cent and sulphur $80 \%$ WP inhibited the mycelial growth $33.74,42.07,60.85$ and 75.00 per cent at 500, 1000, 1500 and 2000 ppm concentrations, respectively these two were found as a least effective non-systemic fungicides. The cumulative mycelial growth inhibition was increased with increased concentration of fungicides. The interaction effect studied between fungicide and its concentrations showed metiram $55 \%$ WG (92.37\%), thiram $75 \%$ WP (91.26\%), propineb $70 \% \mathrm{WP}(90.89 \%)$ and mancozeb $75 \%$ WP (90.96\%) at $2000 \mathrm{ppm}$ were on par with each other whereas mancozeb $75 \% \mathrm{WP}$ at $1000 \mathrm{ppm}(88.89 \%)$ and $1500 \mathrm{ppm}(90.04$ $\%)$, propineb $70 \% \mathrm{WP}$ at $1500 \mathrm{ppm}(90.21$ $\%$ ) and 2000 ppm (90.89\%), metiram $55 \%$ WG at 1500 ppm (90.00\%) were on par with each other in inhibiting radial growth of mycelium. The effectiveness of mancozeb in inhibiting the growth of $A$. triticina has been reported by Sankhla et al., (1972). Mancozeb showed maximum mean mycelial growth inhibition of Alternaria triticina in present study, agreement with results obtained by Bhowmick (1974) and Sahu et al., (2013).

Among different systemic fungicides tested propiconazole $25 \% \mathrm{EC}$ found the best among all treatments and gave 84.00, 100.00, 100.00 and 100.00 per cent inhibition of growth of the fungus at 50, 100, 250 and $500 \mathrm{ppm}$ concentrations, respectively under in vitro condition. Hexaconazole 5\% EC was found as a second best fungicide with 85.07, 85.93, 90.30 and 100.00 per cent mycelial growth at $50,100,250$ and $500 \mathrm{ppm}$ concentrations, respectively. Next to it azoxystrobin $23 \%$ SC was found effective with mycelia growth inhibition per cent of $65.96,67.81,77.85$ and 81.63 at $50,100,250$ and $500 \mathrm{ppm}$ concentrations respectively. Carbendazim 50 $\%$ WP showed mycelia growth inhibition (48.93, 52.15, 66.30 and 70.81), thiophanate methyl $70 \%$ WP showed $(54.44,57.15,60.74$ and 63.44), fosetyl -Al showed (43.11, 51.48, 63.30 and 73.52) and picoxystrobin $25 \% \mathrm{EC}$ showed 38.93, 54.44, 60.48 and 73.30 mycelial growth inhibition at 50, 100, 250 and 500 ppm, respectively. The cumulative mycelial growth inhibition was increased with increased concentration of fungicides. The interaction effect studied between fungicide and its concentrations showed hexaconazole 5 $\%$ EC at 500 ppm (100\%) and propiconazole $25 \%$ EC at 100,250 and 500 ppm (100\%) were on par with each other whereas hexaconazole $5 \% \mathrm{EC}$ at $50 \mathrm{ppm}(85.07 \%)$, $100 \mathrm{ppm}(85.93 \%)$ and propiconazole $25 \%$ $\mathrm{EC}$ at $50 \mathrm{ppm}(84.0 \%)$ were on par with each other. This findings are in conformity with earlier studies of Patel (2008) and Ginoya and Gohel (2015) who reported cent per cent inhibition of radial growth of fungus $A$. alternata with propiconazole.

Among different combination fungicides tested azoxystrobin $11 \%+$ tebuconazole $18.30 \% \mathrm{WP}$, hexaconazole $4 \%$ + zineb $68 \%$ WP and carboxin $37.5 \%$ + thiram $37.5 \%$ SD were significantly superior over rest of the treatments gave mean mycelial growth inhibition cent per cent. Next to it, cymoxanil $8 \%+$ mancozeb $64 \%$ WP was found effective with mycelial growth inhibition per cent of $75.81,80.89,86.15$ and 90.89 at 100 , 250, 500 and 1000 ppm, respectively. Carbendazim $12 \%+$ mancozeb $63 \%$ WP showed mycelial growth inhibition of 64.96 , 77.33, 80.52 and 88.52, tricyclazole $18 \%+$ mancozeb $62 \%$ WP showed 55.93, 66.15, 84.07 and 87.19 and tebuconazole $50 \%+$ trifloxystrobin $25 \%$ WG showed 54.56, 58.07, 87.89 and 90.70 at 100, 250, 500 and 1000 ppm, respectively (Table 1-3). 
Table.1 Effect of different non-systemic fungicides on mycelial growth inhibition of $A$. triticina under in vitro condition

\begin{tabular}{|c|c|c|c|c|c|c|}
\hline \multirow{2}{*}{$\begin{array}{l}\text { Sr. } \\
\text { No. }\end{array}$} & \multirow[t]{2}{*}{ Fungicides } & \multicolumn{4}{|c|}{ *Growth inhibition (\%) } & \multirow{2}{*}{$\begin{array}{c}\text { Mean } \\
\text { inhibitior } \\
(\%)\end{array}$} \\
\hline & & 500 ppm & $\begin{array}{l}1000 \\
\text { ppm }\end{array}$ & $\begin{array}{l}1500 \\
\text { ppm }\end{array}$ & 2000 ppm & \\
\hline 1 & Mancozeb (75\%WP) & $\begin{array}{c}87.74 \\
(69.54)^{\#}\end{array}$ & $\begin{array}{c}88.89 \\
(70.56)\end{array}$ & $\begin{array}{l}90.04 \\
(71.64)\end{array}$ & $\begin{array}{l}90.96 \\
(72.54)\end{array}$ & $\begin{array}{c}89.41 \\
(71.07)\end{array}$ \\
\hline 2 & Propineb (70 \%WP) & $\begin{array}{c}86.15 \\
(68.18)\end{array}$ & $\begin{array}{c}87.56 \\
(69.38)\end{array}$ & $\begin{array}{c}90.21 \\
(71.80)\end{array}$ & $\begin{array}{l}90.89 \\
(72.47)\end{array}$ & $\begin{array}{l}88.70 \\
(70.46)\end{array}$ \\
\hline 3 & $\begin{array}{l}\text { Copper Oxy chloride } \\
(50 \% \text { WP) }\end{array}$ & $\begin{array}{c}53.70 \\
(47.15)\end{array}$ & $\begin{array}{l}65.96 \\
(54.34)\end{array}$ & $\begin{array}{c}75.52 \\
(60.37)\end{array}$ & $\begin{array}{l}76.41 \\
(60.97)\end{array}$ & $\begin{array}{l}67.90 \\
(55.71)\end{array}$ \\
\hline 4 & Metiram (55 \%WG) & $\begin{array}{l}75.78 \\
(60.55)\end{array}$ & $\begin{array}{c}86.85 \\
(68.77)\end{array}$ & $\begin{array}{l}90.00 \\
(71.60)\end{array}$ & $\begin{array}{l}92.37 \\
(74.00)\end{array}$ & $\begin{array}{c}86.25 \\
(68.73)\end{array}$ \\
\hline 5 & Sulphur (80 \%WP) & $\begin{array}{c}33.74 \\
(35.53)\end{array}$ & $\begin{array}{c}42.07 \\
(40.46)\end{array}$ & $\begin{array}{c}60.85 \\
(51.29)\end{array}$ & $\begin{array}{l}75.00 \\
(60.03)\end{array}$ & $\begin{array}{c}52.92 \\
(46.83)\end{array}$ \\
\hline 6 & Thiram (75\%WP) & $\begin{array}{c}80.74 \\
(64.00)\end{array}$ & $\begin{array}{l}84.07 \\
(66.51)\end{array}$ & $\begin{array}{l}88.78 \\
(70.46)\end{array}$ & $\begin{array}{l}91.26 \\
(72.84)\end{array}$ & $\begin{array}{c}86.21 \\
(68.45)\end{array}$ \\
\hline 7 & Zineb (75 \%WP) & $\begin{array}{c}64.22 \\
(53.29)\end{array}$ & $\begin{array}{c}65.44 \\
(54.02)\end{array}$ & $\begin{array}{c}70.44 \\
(57.10)\end{array}$ & $\begin{array}{c}84.33 \\
(66.72)\end{array}$ & $\begin{array}{l}71.11 \\
(57.78)\end{array}$ \\
\hline \multirow{2}{*}{\multicolumn{2}{|c|}{ Mean }} & $\begin{array}{c}68.87 \\
(56.89)\end{array}$ & $\begin{array}{c}74.41 \\
(60.58)\end{array}$ & $\begin{array}{c}80.83 \\
(64.07)\end{array}$ & $\begin{array}{c}85.89 \\
(67.97)\end{array}$ & - \\
\hline & & \multicolumn{2}{|c|}{ Between Fungicide(F) } & \multicolumn{2}{|c|}{$\begin{array}{l}\text { Within fungicide } \\
\text { Concentration(C) }\end{array}$} & $\mathbf{F} \times \mathbf{C}$ \\
\hline & S.Em. \pm & \multicolumn{2}{|c|}{0.34} & \multicolumn{2}{|c|}{0.26} & 0.69 \\
\hline & C.D at $5 \%$ & \multicolumn{2}{|c|}{0.98} & \multicolumn{2}{|c|}{0.76} & 1.96 \\
\hline & CV\% & \multicolumn{5}{|c|}{1.90} \\
\hline
\end{tabular}

* Mean of three replications

${ }^{\#}$ Data in parentheses are arcsine transformed and outside are retransformed values. 
Table.2 Effect of different systemic fungicides on mycelial growth inhibition of $A$. triticina under in vitro condition

\begin{tabular}{|c|c|c|c|c|c|c|}
\hline \multirow{2}{*}{$\begin{array}{l}\text { Sr. } \\
\text { No. }\end{array}$} & \multirow{2}{*}{ Fungicides } & \multicolumn{4}{|c|}{ *Growth inhibition (\%) } & \multirow{2}{*}{$\begin{array}{c}\text { Mean inhibition } \\
(\%)\end{array}$} \\
\hline & & $\begin{array}{c}50 \\
\text { ppm }\end{array}$ & $\begin{array}{l}100 \\
\text { ppm }\end{array}$ & $\begin{array}{l}\text { 250 } \\
\text { Ppm }\end{array}$ & $\begin{array}{l}500 \\
\text { ppm }\end{array}$ & \\
\hline 1 & $\begin{array}{l}\text { Azoxystrobin } \\
23 \% \text { SC }\end{array}$ & $\begin{array}{c}65.96 \\
(54.34)^{\#}\end{array}$ & $\begin{array}{c}67.81 \\
(55.46)\end{array}$ & $\begin{array}{c}77.85 \\
(61.96)\end{array}$ & $\begin{array}{c}81.63 \\
(64.65)\end{array}$ & $\begin{array}{c}73.31 \\
(59.10)\end{array}$ \\
\hline 2 & $\begin{array}{l}\text { Carbendazim } \\
50 \% \mathrm{WP}\end{array}$ & $\begin{array}{c}48.93 \\
(44.41)\end{array}$ & $\begin{array}{c}52.15 \\
(46.25)\end{array}$ & $\begin{array}{c}66.30 \\
(54.54)\end{array}$ & $\begin{array}{c}70.81 \\
(57.33)\end{array}$ & $\begin{array}{c}59.54 \\
(50.63)\end{array}$ \\
\hline 3 & $\begin{array}{l}\text { Fosetyl-Al } \\
80 \% \mathrm{WP}\end{array}$ & $\begin{array}{c}43.11 \\
(41.06)\end{array}$ & $\begin{array}{c}51.48 \\
(45.87)\end{array}$ & $\begin{array}{c}63.30 \\
(52.74)\end{array}$ & $\begin{array}{c}73.52 \\
(59.06)\end{array}$ & $\begin{array}{c}57.85 \\
(49.68)\end{array}$ \\
\hline 4 & $\begin{array}{l}\text { Hexaconazole } \\
5 \% \text { EC }\end{array}$ & $\begin{array}{c}85.07 \\
(67.31)\end{array}$ & $\begin{array}{c}85.93 \\
(68.00)\end{array}$ & $\begin{array}{c}90.30 \\
(71.89)\end{array}$ & $\begin{array}{l}100.00 \\
(90.05)\end{array}$ & $\begin{array}{c}90.33 \\
(74.31)\end{array}$ \\
\hline 5 & $\begin{array}{l}\text { Picoxystrobin } \\
25 \% \text { EC }\end{array}$ & $\begin{array}{c}38.93 \\
(38.62)\end{array}$ & $\begin{array}{c}55.44 \\
(48.15)\end{array}$ & $\begin{array}{c}60.48 \\
(51.08)\end{array}$ & $\begin{array}{c}73.30 \\
(58.91)\end{array}$ & $\begin{array}{c}57.03 \\
(49.19)\end{array}$ \\
\hline 6 & $\begin{array}{l}\text { Propiconazole } \\
25 \% \text { EC }\end{array}$ & $\begin{array}{c}84.00 \\
(66.46)\end{array}$ & $\begin{array}{l}100.00 \\
(90.05)\end{array}$ & $\begin{array}{l}100.00 \\
(90.05)\end{array}$ & $\begin{array}{l}100.00 \\
(90.05)\end{array}$ & $\begin{array}{c}96.00 \\
(84.15)\end{array}$ \\
\hline 7 & $\begin{array}{l}\text { Thiophanate methyl } \\
70 \% \text { WP }\end{array}$ & $\begin{array}{c}54.44 \\
(47.57)\end{array}$ & $\begin{array}{c}57.15 \\
(49.13)\end{array}$ & $\begin{array}{c}60.74 \\
(51.23)\end{array}$ & $\begin{array}{c}63.44 \\
(52.83)\end{array}$ & $\begin{array}{c}58.94 \\
(50.19)\end{array}$ \\
\hline \multirow{2}{*}{\multicolumn{2}{|c|}{ Mean }} & $\begin{array}{c}60.06 \\
(51.40)\end{array}$ & $\begin{array}{c}67.14 \\
(57.56)\end{array}$ & $\begin{array}{c}74.14 \\
(61.93)\end{array}$ & $\begin{array}{l}80.38 \\
(67.55)\end{array}$ & - \\
\hline & & \multicolumn{2}{|c|}{$\begin{array}{c}\text { Between } \\
\text { Fungicide (F) }\end{array}$} & \multicolumn{2}{|c|}{$\begin{array}{l}\text { Within fungicide } \\
\text { Concentration (C) }\end{array}$} & F $\times C$ \\
\hline & S.Em. \pm & \multicolumn{2}{|c|}{0.37} & \multicolumn{2}{|c|}{0.28} & 0.74 \\
\hline & C. D. at $5 \%$ & \multicolumn{2}{|c|}{1.05} & \multicolumn{2}{|c|}{0.81} & 2.11 \\
\hline & C.V. \% & \multicolumn{5}{|c|}{2.16} \\
\hline
\end{tabular}

* Mean of three replications

${ }^{\sharp}$ Data in parentheses are arcsine transformed and outside are retransformed values. 
Table.3 Effect of different combination fungicides on mycelial growth inhibition of $A$. triticina under in vitro condition

\begin{tabular}{|c|l|c|c|c|c|c|}
\hline \multirow{2}{*}{$\begin{array}{c}\text { Sr. } \\
\text { No. }\end{array}$} & Fungicide & \multicolumn{3}{|c|}{ *Growth inhibition (\%) } & Mean \\
inhibition \\
\cline { 3 - 6 }
\end{tabular}

* Mean of three replications

\# Data in parentheses are arcsine transformed and outside are retransformed values 
The cumulative mycelial growth inhibition was increased with increased concentration of fungicides. The interaction effect studied between fungicide and its concentrations showed cymoxanil $8 \%+$ mancozeb $64 \%$ WP at $1000 \mathrm{ppm}(90.89 \%)$ and tebuconazole 50 $\%+$ trifloxystrobin $25 \% \mathrm{WG}$ at $1000 \mathrm{ppm}$ $(90.70 \%)$ on par with each other whereas tebuconazole $50 \%+$ trifloxystrobin $25 \%$ $\mathrm{WG}$ at $500 \mathrm{ppm}(87.89 \%)$, tricyclazole $18 \%$ + mancozeb $62 \% \mathrm{WP}$ at $1000 \mathrm{ppm}(87.19 \%)$ and carbendazim $12 \%+$ mancozeb $63 \% \mathrm{WP}$ at $1000 \mathrm{ppm}(88.52 \%)$ were on par with each other. Next to it, cymoxanil $8 \%+$ mancozeb $64 \% \mathrm{WP}$ at $500 \mathrm{ppm}(86.15 \%)$ and tricyclazole $18 \%+$ mancozeb $62 \% \mathrm{WP}$ at $1000 \mathrm{ppm}(87.19 \%)$ on par with each other in inhibiting radial growth of mycelium. In present investigation, hexaconazole $4 \%+$ zineb $68 \%$ WP, azoxystrobin $11 \%+$ tebuconazole $18.30 \% \mathrm{WP}$ and carboxin 37.5 $\%$ + thiram $37.5 \%$ SD were found as a most effective fungicide in inhibition of radial growth of $A$. triticina has reported by Patel (2008) and Ginoya and Gohel (2015).

Among the non-systemic fungicides tested under in vitro condition, mancozeb $75 \% \mathrm{WP}$ and propineb $70 \% \mathrm{WP}$ were found the most effective with 89.41 and 88.70 per cent fungal growth inhibition respectively. While copper oxychloride $50 \%$ WP was least effective even at higher concentration. In case of systemic fungicides propiconazole $25 \% \mathrm{EC}$ and hexaconazole $5 \%$ SC proved the most effective with 96.00 and 90.33 per cent mean fungal growth inhibition. During laboratory screening of combination fungicides, azoxystrobin $11 \%$ + tebuconazole $18.30 \%$ $\mathrm{WP}$, hexaconazole $4 \%+$ zineb $68 \% \mathrm{WP}$ and carboxin $37.5 \%$ + thiram $37.5 \%$ SD were found most effective with cent per cent growth inhibition of fungus. In all the fungicides bioassay studies, with increase in the concentration there was corresponding decrease in the growth of fungus.

\section{Acknowledgement}

The first author is grateful to Department of Plant Pathology, Junagadh Agricultural University for providing laboratory equipments and required things for completing research work.

\section{References}

Anonymous, 2017. Directorate of Economics and Statistics. Department of Agriculture, Cooperation Farmers welfare, Ministery of Agriculture and Farmers Welfare http//:enads.dacnet.nic.in accessed on 26-02-2018.

Anonymous. 2018. World Agricultural Production. United States Department of Agriculture (USDA), Foreign Agricultural Service. Available at https://apps.fas.usda.gov/ accessed on $30^{\text {th }}$ October, 2018.

Bagchi, B. N., and Das, C. R. 1968. Studies on the biological spectrum and sensitivity of some fungicides. Indian Phytopathology. 21, 397-400.

Bhowmick, T. P., 1974. Fungicidal control of Alternaria leaf blight of wheat. Indian Phytopathology. 27(2): 162-167.

Ginoya, C. M., and Gohel, N. M. 2015. Evaluation of newer fungicides against Alternaria alternata (Fr.) Keissler causing fruit rot disease of chilli. International Journal on Plant Protection. 8(1): 169-173.

Patel, R. C., 2008. Studies on fruit rot (Alternaria alternata Fr. Keissler) of chilli (Capsicum annum L.) and its management. M.Sc. (Agri.) Thesis, Anand Agricultural University, Anand (Gujarat).

Sahu, D. K., C. P. Khare, H. K. Singh and Thakur, M. P. 2013. Evaluation of newer fungicide for management of early blight of tomato in Chhattisgarh. 
The Bioscience. 8(4): 1255-1259.

Sankhla, B., H. C. Sankhla, G. G. Dalela and Mathur, R. L. 1972. Evaluation of fungicides against blight disease of wheat caused by Alternaria triticina.
Indian Phytopathology. 25(2): 210-214. Vincent, J. M., 1947. Distortion of fungal hyphae in the presence of certain inhibitors. Nature. 159(4051): 850.

\section{How to cite this article:}

Mahesh Kommeta, I.B. Kapadiya and Akbari, L.F. 2019. Evaluation of Different Fungicides against Leaf Blight (Alternaria triticina) of Wheat under in vitro Condition. Int.J.Curr.Microbiol.App.Sci. 8(06): 1751-1758. doi: https://doi.org/10.20546/ijcmas.2019.806.209 